\title{
FIRST RECORD OF ATRACTUS MANIZALESENSIS PRADO, 1940 (SQUAMATA: COLUBRIDAE: DIPSADINAE) FROM THE DEPARTMENT OF ANTIOQUIA, COLOMBIA
}

\section{PRIMER REGISTRO DE ATRACTUS MANIZALESENSIS PRADO, 1940 (SQUAMATA: COLUBRIDAE: DIPSADINAE) EN EL DEPARTAMENTO DE ANTIOOUIA, COLOMBIA}

\section{LUIS ENRIQUE VERA-PÉREZ}

Independent researcher, carrera 8 \# 2A-12, Las Quintas, La Plata, Huila, Colombia.

Correspondence:dipsadini@gmail.com

Atractus Wagler, 1828 is the most speciose genus of snakes in the world, with 143 valid species, from which 18 have been described in the course of the present decade (Uetz et al., 2019). With the exception of a single species present in Gorgona Island (A. medusa), this genus is confined almost entirely to the South American mainland, extending northward only to Central Panama (Myers \& Schargel, 2006; Passos et al., 2009b; Wallach et al., 2014). However, the greatest diversity of the genus occurs in the Andes, particularly in Colombia, the country with the highest diversity of Atractus, with 64 species recorded (40

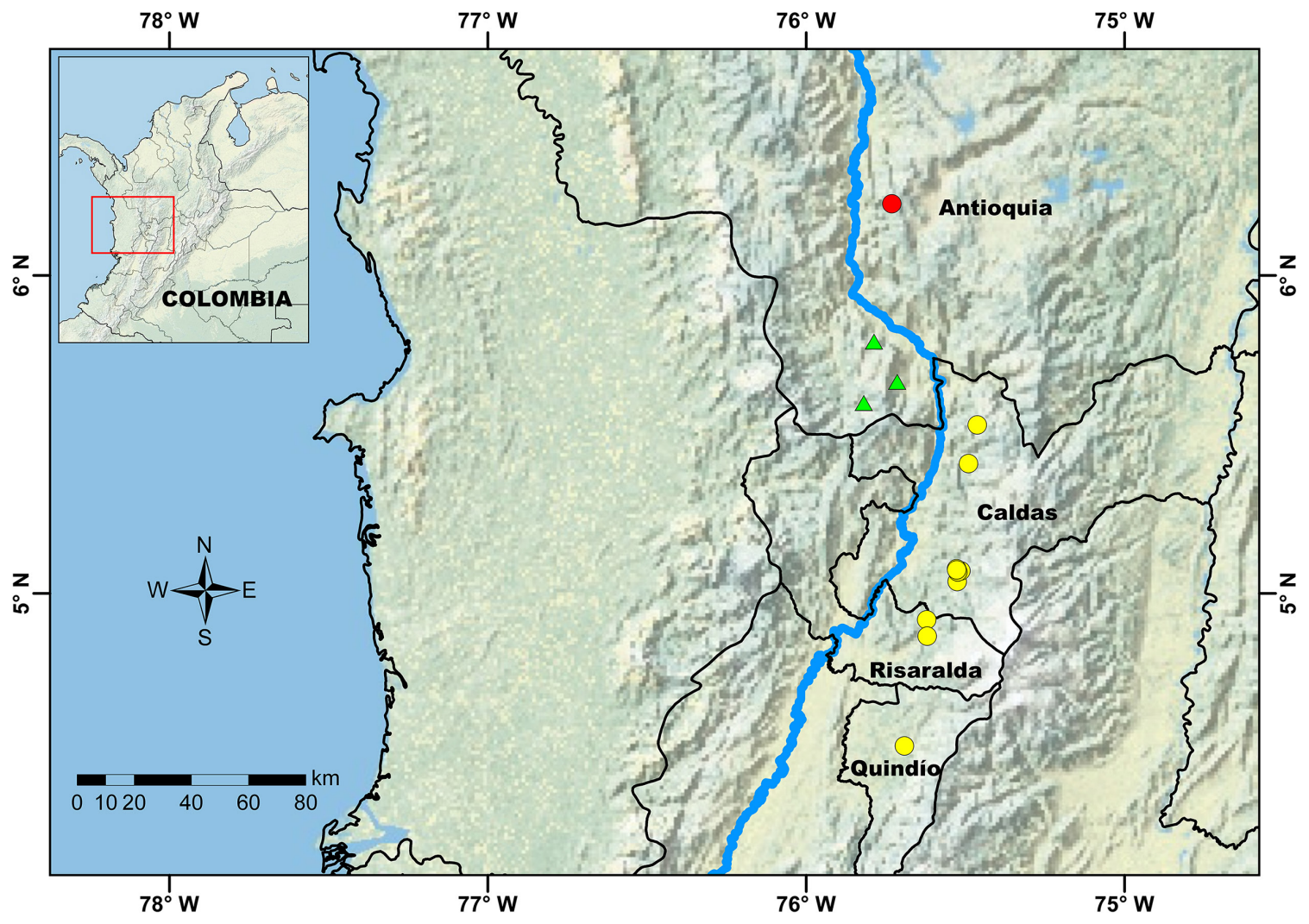

Figura 1. Distribución geográfica de Atractus manizalesensis (puntos) y localidades de A. nicefori (triángulos). Los puntos amarillos representan las localidades previamente reportadas por Passos et al. (2009a) y Rojas-Morales et al. (2017), y el punto rojo indica la nueva localidad reportada en esta nota. La línea azul representa el río Cauca.

Figure 1. Geographic distribution of Atractus manizalesensis (dots) and localities of A. nicefori (triangles). Yellow dots represent localities previously reported by Passos et al. (2009a) and Rojas-Morales et al. (2017), and the red dot indicates the new locality reported in this note. The blue line represents the Cauca river. 
endemic) (Passos \& Arredondo, 2009; Passos et al., 2009a, b; Passos \& Lynch, 2010; Uetz et al. 2019).

One of the endemic Colombian species of Atractus is A. manizalesensis, known only from sub-Andean forests and urban and peri-urban areas of the Western flank of the Cordillera Central of Colombia, between 1500-2160 m from the municipality of Armenia, department of Quindío to Pácora, department of Caldas (Passos et al., 2009a; Rojas-Morales et al., 2017). In total, the distribution of this species only covers around $115 \mathrm{~km}$ in a straight line between the northern and southernmost localities. This note presents the first record of $A$. manizalesensis in the department of Antioquia, Colombia (Fig. 1).

A single individual of Atractus manizalesensis was captured on 22 August 2016 by LEV-P at vereda Monteadentro, municipality of Heliconia $\left(6^{\circ} 13^{\prime} 30.2^{\prime \prime} \mathrm{N}, 75^{\circ} 43^{\prime} 50.2^{\prime \prime} \mathrm{W}, 1771 \mathrm{~m}\right)$. The individual was found at night while it was descending on a big rock, beside a small ravine located inside a patch of secondary forest.

The specimen (Fig. 2) was deposited in the herpetological collection of the Museo de Historia Natural, Universidad del Cauca (MHNUC-HE-Se-0694) in Popayán, Colombia, and it was verified by Gustavo González Durán, herpetologist from the Wildlife Conservation Society of Colombia. It is an adult female of snout-vent length $(\mathrm{SVL})=432 \mathrm{~mm}$, caudal length $(C L)=45 \mathrm{~mm}$, with long loreal (sensu Passos et al, 2007), two postoculars and $1+2$ temporals. The specimen is identified as Atractus manizalesensis according to the diagnostic characters for females selected by Passos et al. (2009a), although it has a greater number of subcaudals (Table 1). In addition, the coloration of

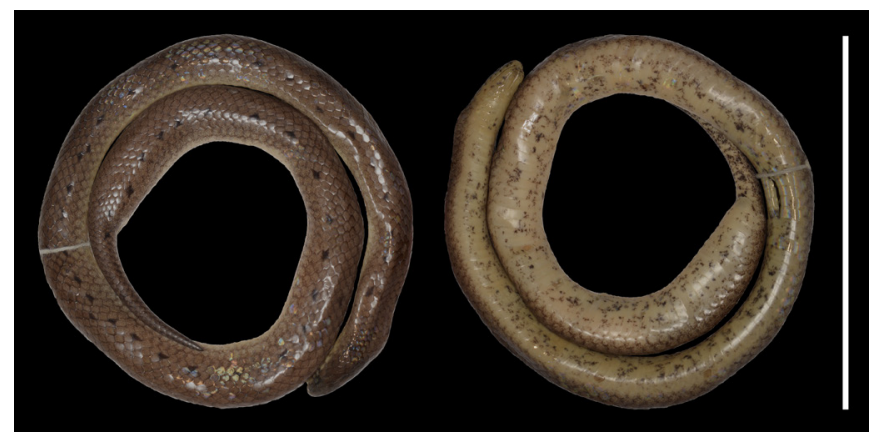

Figura 2. Vista dorsal (izquierda) y ventral (derecha) de Atractus manizalesensis (MHNUC-HE-Se-0694) de la vereda Monteadentro, municipio de Heliconia, departamento de Antioquia, Colombia. Barra de escala $=100 \mathrm{~mm}$.

Figure 2. Dorsal (left) and ventral (right) views of Atractus manizalesensis (MHNUC-HESe-0694) from vereda Monteadentro, municipality of Heliconia, department of Antioquia, Colombia. Scale bar $=100 \mathrm{~mm}$.

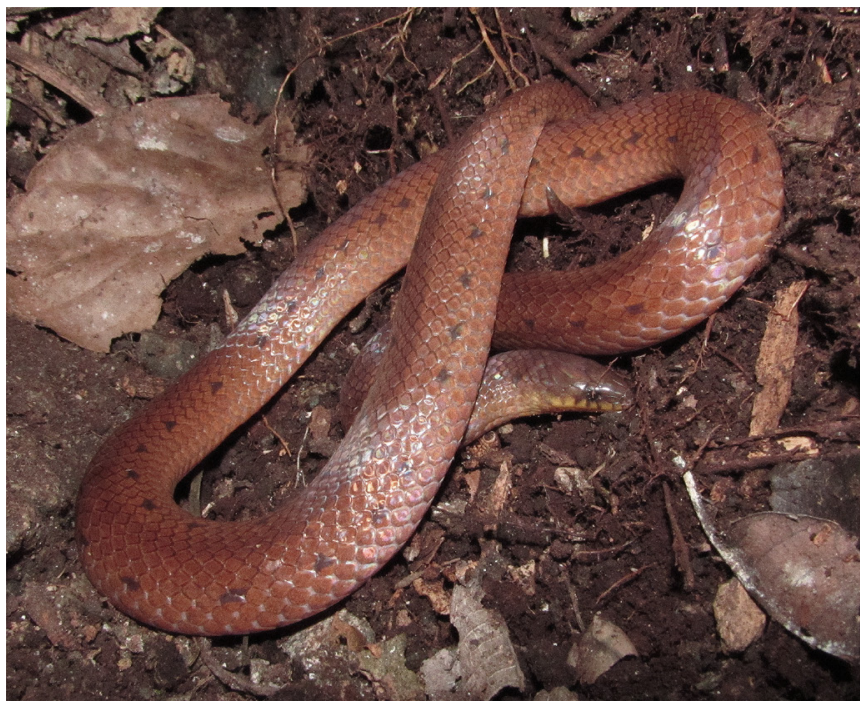

Figura 3. Individuo de Atractus manizalesensis (MHNUC-HE-Se-0694) tras su captura en la vereda Monteadentro, municipio de Heliconia, departamento de Antioquia, Colombia.

Figure 3. Individual of Atractus manizalesensis (MHNUC-HE-Se-0694) upon its capture in vereda Monteadentro, municipality of Heliconia, department of Antioquia, Colombia.

specimen MHNUC-HE-Se-0694 is the same as that provided in the original description by Prado (1940), as complemented by Rojas-Morales et al. (2017): brown dorsal ground color with dark brown spots on each side of the body, yellowish labial and gular regions, and cream venter with profuse gray or black stipples that cover almost all scales to the tail (Figs. 2, 3).

In relation to its congeners distributed from the Eastern slopes of the Cordillera Occidental, the Cordillera Central and the upper and middle Magdalena drainage of Colombia, Atractus manizalesensis is easily differentiated from $A$. andinus, A. apophis, A. atratus, A. attenuatus, A. chthonius, A. lehmanni, A. loveridgei, A. melanogaster, A. nasutus, A. obesus, A. obtusirostris, A. sanguineus and $A$. werneri by having dorsal scales in 15 rows (vs. dorsal scales in 17 rows) (Boettger, 1898; Passos et al., 2009a; Passos \& Lynch, 2010). From geographically related species with 15 dorsal scale rows A. manizalesensis differs from A. biseriatus and A. paisa mainly by having a dorsal color pattern beige to pale brown ground color with paired black dots or irregular transversal blotches (vs. dark brown ground color with cream-white transversal blotches and black ground color uniformly scattered with small creamyellow dots, respectively), and from A. oculotemporalis by having fewer number of subcaudals (14-22) and CL/SVL ratio (8-10.5) in females (vs. 27 and 11.4, respectively) and two postoculars (vs. postoculars absent) (Amaral, 1932; Passos et al., 2009a). 
Tabla 1. Comparación de varios caracteres de diagnóstico de Atractus manizalesensis resumidos por Passos et al. (2009a), y valores del espécimen MHNUC-HE-Se-0694. La barra oblicua separa el recuento de los lados derecho/izquierdo.

Table 1. Comparison of several diagnostic characters from Atractus manizalesensis summarized by Passos et al. (2009a), and values from specimen MHNUC-HE-Se-0694. Oblique bar separates count of the right/left sides.

\begin{tabular}{cccc}
\hline & \multicolumn{2}{c}{ Passos et al. (2009a) } & MHNUC-HE-Se-0694 \\
\hline Sex & $\begin{array}{c}\text { Males } \\
(\mathrm{n}=8)\end{array}$ & $\begin{array}{c}\text { Females } \\
(\mathrm{n}=16)\end{array}$ & Female \\
Dorsal scale rows & \multicolumn{2}{c}{15} & 15 \\
Ventrals & $139-145$ & $143-154$ & 146 \\
Subcaudals & $17-23$ & $14-22$ & 25 \\
Supralabials & \multicolumn{2}{c}{$7-8$} & $7 / 8$ \\
Infralabials & \multicolumn{2}{c}{$7-8$} & 9 \\
Maxillary teeth & \multicolumn{2}{c}{$9-11$} & 10.4 \\
CL/SVL ratio & $10.5-15.9$ & $8-10.5$ & $7 / 8$ \\
\hline
\end{tabular}

Atractus manizalesensis is more similar to A. nicefori, as the diagnostic characters of both species completely overlap for the case of females, while males only differ in the number of subcaudal scales (Passos et al., 2009a). Thus, the specimen MHNUC-HE-Se-0694 could be identified as A. nicefori because the number of subcaudals is within the range of that species (19-26 in females). However, A. nicefori has a gray belly profusely spotted with pinkish-yellow (Amaral, 1930), while the belly of A. manizalesensis is creamish white to yellow background with profuse dark spots (Prado, 1940; Rojas-Morales et al., 2017). In addition, the distribution of both species is isolated by the inter-Andean depression between the Cordillera Occidental and Cordillera Central drained by Cauca river (Fig. 1). All locality records for geographically close congeners (Marx, 1960; Myers \& Schargel, 2006; Passos et al., 2009a; Vanegas-Guerrero et al., 2014) show that the Valley and middle Cauca river drainage could be a potential geographic barrier for those species too: A. andinus, A. loveridgei, A. obesus and A. oculotemporalis are restricted to Cordillera Occidental; in contrast with A. attenuatus, A. biseriatus, A. nasutus, A. paisa, A. sanguineus and A. titanicus, which are distributed in the Cordillera Central.

Finally, the record of Atractus manizalesensis presented herein extends the known range of the subcaudal scales for females of this species, and represents the first record in the department of Antioquia extending its geographical distribution northwards in around $82 \mathrm{~km}$ in a straight line from the municipality of Pácora, department of Caldas. This finding also implies a positive impact for the conservation of A. manizalesensis, specially by the less impact of human activities observed at the new locality and surrounding area, since the species is apparently vulnerable among the previously known localities due to the habitat destruction, roadkill and direct killing by humans (RojasMorales, 2012; Rojas-Morales et al., 2017).

Acknowledgments.- Thanks go to Andrés Felipe Liévano Bonilla from the herpetological collection of MHNUC and Gustavo González Durán for the unconditional support they have given to me. To Juan Pablo Ramírez and Juana Parada Sierra for reading the manuscript and providing valuable suggestions. Special thanks to Juan Ricardo Olmos for including me in the field work from which the species was found. The specimen MHNUC-HESe-0694 was collected under the project "Plan de Ordenación y Manejo de la cuenca hidrográfica de los directos río Cauca río Amagá, quebrada Sinifaná (cód. 2620-01), localizada en el departamento de Antioquia", contract number $\mathrm{CN}-1512-252$ of 2015 signed by CORANTIOQUIA and CPA Ingeniería S.A.S.

\section{CITED LITERATURE}

Amaral, A. 1930. Studies of Neotropical Ophidia. XVI. Two new snakes from Central Colombia. Bulletin of Antivenin Institute of America 4:27-28.

Amaral, A. 1932. Studies of Neotropical Ophidia. XXVII. On two small collections of snakes from Central Colombia. Bulletin of Antivenin Institute of America 5:66-68.

Boettger, O. 1898. Katalog der Reptilien-Sammlung in Museum der Senckenbergischen Naturforschenden Gesellschaft in Frankfurt am Main. II Teil (Schlangen). Gebrüder Knauer, Frankfurt, Germany.

Marx, H. 1960. A new colubrid snake of the genus Atractus. Fieldiana. Zoology 39:411-413.

Myers, C.W. \& E.S. Schargel. 2006. Morphological Extremes-Two New Snakes of the Genus Atractus from Northwestern South America (Colubridae: Dipsadinae). American Museum Novitates 3532:1-13.

Passos, P., D.F. Cisneros-Heredia \& D. Salazar-V. 2007. Rediscovery and redescription of the rare Andean snake Atractus modestus. Herpetological Journal 17:1-6. 
Passos, P. \& J.C. Arredondo. 2009. Rediscovery and redescription of the Andean earth-snake Atractus wagleri (Reptilia: Serpentes: Colubridae). Zootaxa 1969:59-68.

Passos, P., J.C. Arredondo, R. Fernandes \& J.D. Lynch. 2009 a. Three New Atractus (Serpentes: Dipsadidae) from the Andes of Colombia. Copeia 3:425-436.

Passos, P., J.J. Mueses-Cisneros, J.D. Lynch \& R. Fernandes. 2009b. Pacific lowland snakes of the genus Atractus (Serpentes: Dipsadidae), with description of three new species. Zootaxa 2293:1-34.

Passos, P. \& J.D. Lynch. 2010. Revision of Atractus (Serpentes: Dipsadidae) from middle and upper Magdalena drainage of Colombia. Herpetological Monographs 24:149-173.

Prado, A. 1940. Notas ofiologicas 4. Cinco especies novas de serpentes colombianas do genero Atractus Wagler. Memorias do Instituto Butantan 13:15-19.
Rojas-Morales, J.A. 2012. Snakes of an urban-rural landscape in the central Andes of Colombia: species composition, distribution, and natural history. Phyllomedusa 11(2):135-154.

Rojas-Morales, J.A., G.A. González-Durán \& M.C. Basto-Riascos. 2017. Atractus manizalesensis Prado 1940. Catálogo de Anfibios y Reptiles de Colombia 3:37-42.

Uetz, P., P. Freed \& J. Hosek (Eds.). 2019. The Reptile Database. http://www.reptile-database.org, [Accessed on 02 March 2020].

Vanegas-Guerrero, J., J.C. Mantilla-Castaño \& P. Passos. 2014 Atractus titanicus Passos, Arredondo, Fernandes \& Lynch, 2009 (Serpentes: Dipsadidae): Filling gaps in its geographical distribution. Check List 10(3):672-673.

Wallach, V., K.L. Williams \& J. Boundy. 2014. Snakes of the World: A Catalogue of Living and Extinct Species. Taylor and Francis Group, CRC Press., Boca Raton, Florida, USA. 